\title{
Change in the Structure of Asphaltene Macromolecules of the Krapivinskoye Oil Field During Biological Oxidation
}

\author{
Tatyana V. Cheshkova, Tatyana A. Sagachenko, \\ Raisa S. Min and Dmitriy A. Philatov* \\ Institute of Petroleum Chemistry SB RAS \\ Tomsk, Russian Federation
}

Received 17.04.2021, received in revised form 06.05.2021, accepted 07.06.2021

\begin{abstract}
Using physico-chemical methods of research (elemental analysis, infrared spectroscopy, selective chemical destruction of sulfide and ester bonds, chromatomass spectrometry) the influence of biodegradation processes on the composition and structure of asphaltenes of light oil at the Krapivinskoye deposit was studied. The results of comparative characteristics of initial asphaltenes and asphaltenes after biodestruction are presented. Attention is paid to studying their structural parameters and composition of fragments bound in asphaltene molecules through ester and sulfide bridges. It has been shown that microbial oxidation of asphaltenes of light oil by aboriginal soil microflora (laboratory experiment) occurs through a series of catalytic processes with formation of intermediate products of transformation - alcohols, aldehydes, ketones and fatty acids. It has been established that "grey and ether-bound" fragments in asphaltene molecules of biodegradable oil differ from "bound" compounds in the structure of the original asphaltenes with the qualitative composition of saturated and aromatic hydrocarbons and heteroatomic components.
\end{abstract}

Keywords: asphaltenes, biodegradation, chemical degradation, composition.

Citation: Cheshkova T.V., Sagachenko T.A., Min R.S., Philatov D.A. Change in the structure of asphaltene macromolecules of the Krapivinskoye oil field during biological oxidation, J. Sib. Fed. Univ. Chem., 2021, 14(2), 252-262. DOI: 10.17516/19982836-0234

(C) Siberian Federal University. All rights reserved

This work is licensed under a Creative Commons Attribution-NonCommercial 4.0 International License (CC BY-NC 4.0).

* Corresponding author E-mail address: chtv12@mail.ru 


\title{
Изменение структуры макромолекул асфальтенов нефти Крапивинского месторождения \\ в процессе биологического окисления
}

\author{
Т.В. Чешкова, Т. А. Сагаченко, \\ Р. С. Мин, Д.А. Филатов \\ Институт химии нефти СО РАН \\ Российская Федераиия, Томск
}

\begin{abstract}
Аннотация. С использованием физико-химических методов исследования (элементный анализ, ИК-спектроскопия, селективная химическая деструкция сульфидных и эфирных связей, хроматомасс-спектрометрия) изучено влияние процессов биодеструкции на состав и структуру асфальтенов легкой нефти Крапивинского месторождения. Приведены результаты сравнительной характеристики исходных асфальтенов и асфальтенов после биодеструкции. Внимание уделено изучению их структурных параметров и состава фрагментов, связанных в молекулах асфальтеновых веществ через эфирные и сульфидные мостики. Показано, что микробное окисление асфальтенов легкой нефти аборигенной почвенной микрофлорой (лабораторный эксперимент) происходит через серию каталитических процессов с образованием промежуточных продуктов превращения - спиртов, альдегидов, кетонов и жирных кислот. Установлено, что «серо- и эфиросвязанные» фрагменты в молекулах асфальтенов биодеградированной нефти различаются от «связанных» соединений в структуре исходных асфальтенов качественным составом насыщенных и ароматических углеводородов и гетероатомных компонентов.
\end{abstract}

Ключевые слова: асфальтены, биодеградация, химическая деструкция, состав.

Цитирование: Чешкова, Т.В. Изменение структуры макромолекул асфальтенов нефти Крапивинского месторождения в процессе биологического окисления / Т. В. Чешкова, Т. А. Сагаченко, Р. С. Мин, Д. А. Филатов // Журн. Сиб. федер. ун-та. Химия, 2021, 14(2). С. 252-262. DOI: 10.17516/1998-2836-0234

\section{Введение}

При добыче, подготовке и транспортировке нефтей неизбежно возникают проблемы, связанные с образованием асфальтосмолопарафиновых отложений (АСПО) в пласте, в скважинном и нефтеперекачивающем оборудовании [1].

Особую роль при формировании АСПО играют асфальтены. Они выступают в качестве центров кристаллизации углеводородов и способствуют укрупнению частиц, превращая их в агрегаты сложной структуры [2, 3].

Для решения вопросов, связанных с АСПО, в последнее время внимание уделяется микробиологическому способу, который является наиболее экологически чистым и наименее затратным из всех известных способов [4].

Впервые участие асфальтенов в процессах микробиологического окисления было показано в работе [5]. Результаты последних исследований [6, 7] подтверждают способность микро-

$$
-253-
$$


организмов окислять высокомолекулярные компоненты. Основная характеристика изменений асфальтенов получена на уровне структурно-группового анализа.

В то же время известно, что в молекулярной структуре асфальтенов важную роль играет сера в сульфидных связях и кислород в эфирных и сложноэфирных связях [8]. Функциональные группы простых и/или сложных эфиров и алифатических сульфидов могут выступать в качестве мостиков, осуществляющих в молекулах асфальтенов связь отдельных структурных фрагментов между собой или с поликонденсированным ядром их молекул [8]. Информация о составе таких фрагментов в структуре асфальтенов биодеградированных нефтей ограничена и касается только углеводородного состава в продуктах их десульфуризации [5].

Следует отметить, что в опубликованной научной литературе представлены результаты, полученные главным образом для асфальтеновых компонентов тяжелых нефтяных систем. В то же время для развития микробиологических способов удаления АСПО необходимо накопление данных о поведении в процессах биодеградации асфальтенов нефтей различной химической природы. В связи с этим в данной работе изучено влияние микробиального окисления на структуру асфальтеновых компонентов легкой нефти.

Исследования выполнены на примере нефти Крапивинского месторождения, расположенного на территории Каргасокского района Томской области. Данное месторождение одно из наиболее крупных в Томской области, его запасы оцениваются в 36,5 млн т [9], в настоящее время находится в активной разработке. Нефть является легкой $(867$ кг/м³ $)$, сернистой $(0,84 \%)$, малопарафинистой $(1,72 \%)$.

В работе приведены сравнительные данные о структуре асфальтенов исходной и биодеградированной крапивинской нефти и о составе структурных фрагментов, связанных в их молекулах и сульфидными и эфирными мостиками.

\section{Экспериментальная часть}

Загрязнение почвы нефтью осуществляли искусственно. В просеянную на сите размером 3 мм и взвешенную почву вносили нефть из расчета 50 г/кг, и смесь тщательно гомогенизировали. Приготовленную таким образом почву с нефтью помещали в стеклянные эксикаторы (толщина слоя почвы 12 см). Модельные почвенные системы инкубировали при температуре 20$22{ }^{\circ} \mathrm{C}$. Влажность почвы поддерживали в диапазоне 26-28 \%. Для экспериментов использовали универсальный почвогрунт «Грант» (производство ПК «Темп-2», Томская область, Россия), полученный путем переработки навоза крупного рогатого скота промышленной популяцией дождевых червей с добавлением низинного торфа, биогумуса и дерновой земли, с высоким содержанием доступных питательных веществ следующего состава: азот $\left(\mathrm{NH}_{4}+\mathrm{NO}_{3}\right)-30$ мг/100 г; фосфор $\left(\mathrm{P}_{2} \mathrm{O}_{5}\right) 70$ мг/100 г; калий $\left(\mathrm{K}_{2} \mathrm{O}\right)-80$ мг/100 г, $\mathrm{pH}=6,5-7,4$.

В ходе эксперимента для аэрации и разрушения пор разного размера (которое, как показывает практика, ускоряет деградацию углеводородов) периодически проводили рыхление почвы. Продолжительность эксперимента составила 180 сут.

Исследования по оценке степени микробного окисления нефти подробно описаны в работе [7].

Остаточное содержание нефти в почве устанавливали гравиметрическим методом. Для этого нефть из загрязненной почвы экстрагировали хлороформом в аппарате Сокслета. Извлеченную нефть освобождали от хлороформа на роторном испарителе и взвешивали.

$$
-254-
$$


Выделение асфальтенов из исходной и биодеградированной нефтей проводили по стандартной методике [10]. Для разрушения эфирных и сульфидных мостиков в образцах асфальтенов исходной и биодеградированной нефти использовали трибромид бора и борид никеля [11]. Жидкие продукты селективных реакций разделяли на силикагеле АСК (100/160) на неполярную и полярную фракции, применяя для десорбции алкилбромидов смеси н-гексана и бензола (7:3 по объему) и спирта и бензола (1:1 по объему), а для десорбции растворимых продуктов десульфуризации - смеси н-гексана и бензола (1:1 по объему) и метанола и хлороформа (1:4 по объему). Алкилбромиды неполярной фракции восстанавливали алюмогидридом лития.

Состав асфальтенов исходной и биодеградированной нефтей охарактеризованы методами, включающими: анализ элементного состава с использованием CHNS-анализатора "Vario EL Cube", ИК-Фурье спектроскопию.

ИК-спектры регистрировали с помощью FT-IR-спектрометра «Nicolet 5700» в диапазоне 4000-400 см с $^{-1}$ Образцы асфальтенов снимали в таблетках с KBr. Из ИК-спектров рассчитывали спектральные коэффициенты C1 = D1600/D720; C2 = D1710/D1465; C3 = D1380/D1465; C4 = D720+D1380/D1600; C5 = D1030/D1465, являющиеся отношением оптических плотностей полос поглощения на частотах 1710, 1600, 1465, 1380, 1030 и $720 \mathrm{~cm}^{-1}$ и отражающие соответственно относительное содержание ароматических структурных фрагментов (C1), карбонильных (C2) и сульфоксидных (С5) функциональных групп, а также долю алифатических структурных фрагментов (С4) и их разветвленность (С3) [12].

Продукты восстановления алкилбромидов и неполярную фракцию продуктов десульфуризации анализировали методом хроматомасс-спектрометрии (ГХ-МС) с использованием DFS прибора фирмы Thermo Scientific. Условия получения спектров, их обработки и подходы к идентификации соединений приведены в работе [8].

\section{Результаты и обсуждения}

В процессе исследования установлено, что асфальтены, относящиеся к трудно утилизируемым компонентам, как в результате биохимического окисления нефти ассоциацией почвенных микроорганизмов, так и под влиянием абиотических факторов среды, разрушаются. Это подтверждает наличие в почве микрофлоры, способной к ассимиляции данных соединений. Биодеструкция нефти за 180 сут составила в среднем 77 \% от исходного загрязнения, деструкция асфальтенов - 16 \%. Из данных табл. 1 следует, что в процессе биодеградации молекулы асфальтенов крапивинской нефти (АКН) претерпевают значительные изменения.

Таблица 1. Характеристика исследуемых объектов

Table 1. Characteristics of the objects of investigation

\begin{tabular}{ccccccc}
\hline \multirow{2}{*}{ Наименование } & \multicolumn{7}{c}{ Количество, \% масс. } \\
\cline { 2 - 7 } & $\mathrm{C}$ & $\mathrm{H}$ & $\mathrm{N}$ & $\mathrm{S}$ & $\mathrm{O}$ & $\mathrm{H} / \mathrm{C}$ \\
\hline АКН & 83,56 & 7,62 & 0,88 & 2,39 & 5,55 & 1,09 \\
АБКН & 78,41 & 8,13 & 1,48 & 0,82 & 11,16 & 1,24 \\
\hline
\end{tabular}


По результатам элементного анализа асфальтены биодеградированной крапивинской нефти (АБКН) характеризуются снижением содержания углерода и серы и более высоким содержанием водорода, азота и кислорода. Повышение атомного отношения Н/С свидетельствует о том, что в процессе биоокисления в молекулах асфальтенов происходит перераспределение гетероатомов. В ИК-спектрах АБКН (рис. 1) появляются отсутствующие в ИК-спектрах АКН полосы поглощения -ОН-групп спиртов $\left(1167 \mathrm{~cm}^{-1}\right)$, а также С-О группы простых и сложных эфиров $\left(1262 \mathrm{~cm}^{-1}\right)$. Появление этих полос поглощения и увеличение значения спектрального коэффициента окисленности $\mathrm{C}_{2}$, который характеризует относительную долю карбоксилсодержащих соединений (табл. 2), напрямую доказывает окислительный характер протекающих процессов биотрансформации геомакромолекул [5].

С окислением связано и увеличение коэффициента $\mathrm{C}_{5}$, который указывает на рост относительного содержания сульфоксидных функциональных групп $\mathrm{S}=\mathrm{O}\left(1033 \mathrm{~cm}^{-1}\right)$ в молекулах АБКН. Это может быть обусловлено тем, что атмосферный или растворенный в воде кислород окисляет сульфидные связи органических соединений до сульфоксидов [13].

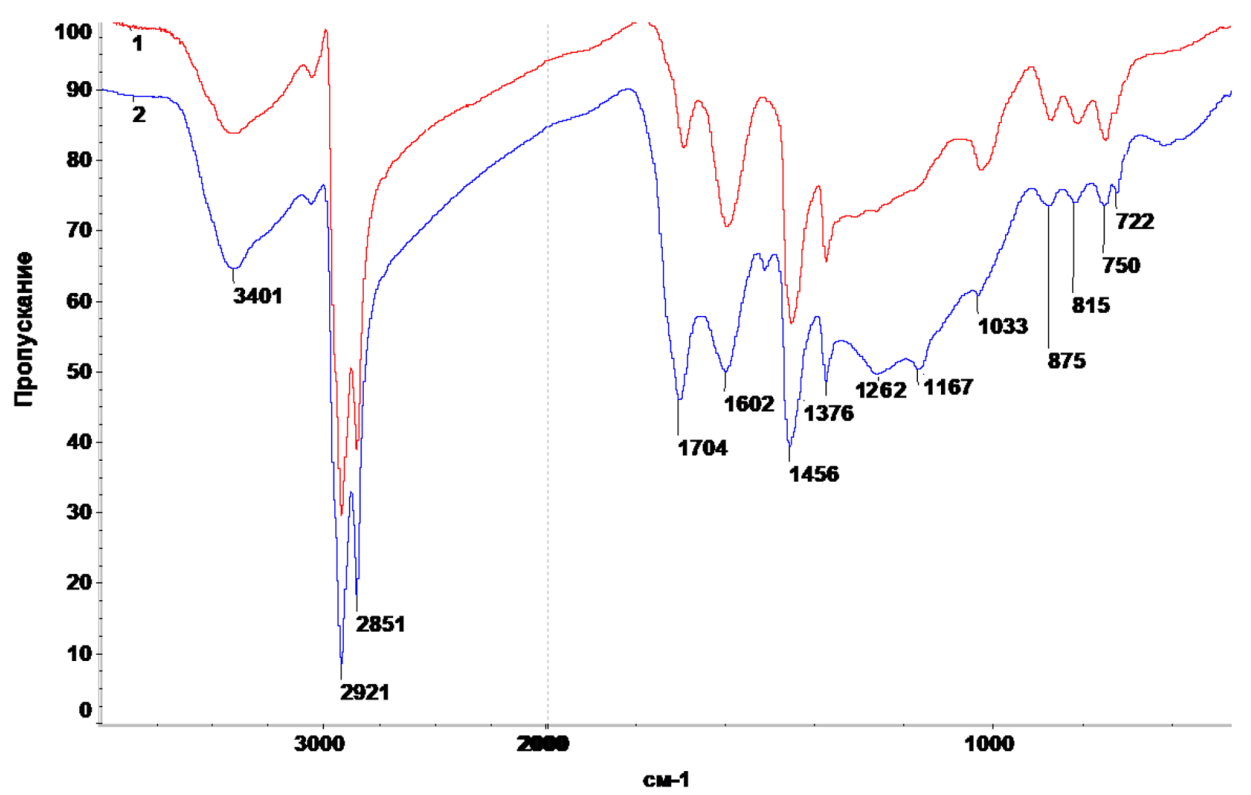

Рис. 1. ИК-спектр АКН (1) и АБКН (2)

Fig. 1. IR spectra of AKO (1) and ABKO (2)

Таблица 2. Спектральные показатели

Table 2. Spectral parameters

\begin{tabular}{|c|c|c|c|c|c|c|c|c|c|c|c|}
\hline \multirow[t]{2}{*}{ Компоненты } & \multicolumn{6}{|c|}{$\begin{array}{c}\text { Оптическая плотность D } \\
\text { в max полосы поглощения, } \mathrm{v} \mathrm{cm}^{-1}\end{array}$} & \multicolumn{5}{|c|}{ Спектральные показатели } \\
\hline & 1710 & 1600 & 1465 & 1380 & 1030 & 720 & $\mathrm{C}_{1}$ & $\mathrm{C}_{2}$ & $\mathrm{C}_{3}$ & $\mathrm{C}_{4}$ & $\mathrm{C}_{5}$ \\
\hline АKH & 0.089 & 0.153 & 0.248 & 0.186 & 0.105 & 0.063 & 2.43 & 0.35 & 0.75 & 1.27 & 0.42 \\
\hline АБКН & 0.254 & 0.224 & 0.309 & 0.235 & 0.152 & 0.071 & 3.17 & 0.82 & 0.76 & 1.11 & 0.49 \\
\hline
\end{tabular}


Из сравнения значений спектральных коэффициентов $\mathrm{C}_{1}, \mathrm{C}_{3}$ и $\mathrm{C}_{4}$ следует, что в структуре молекул АБКН выше доля ароматических и ниже доля алифатических фрагментов, степень разветвленности которых практически не меняется (табл. 2).

В табл. 3 приведены результаты ГХ-МС анализа продуктов химической деструкции образцов асфальтенов исходной и биодеградированной нефтей. Качественный анализ данных показал, что в составе «серосвязанных» фрагментов АКН и АБКН присутствуют алканы, моно- и полициклические нафтены, моно- и полициклические ароматические УВ и гетероорганические соединения.

Алканы исследуемых продуктов десульфуризации представлены гомологическими рядами нормальных и разветвленных алканов (рис. 2).

Таблица 3. Перечень идентифицированных соединений в продуктах химической деструкции АКН и АБКН

Table 3. List of identified compounds in products of chemical destruction of AKO and ABKO

\begin{tabular}{|c|c|c|c|c|c|}
\hline \multirow{3}{*}{$\begin{array}{c}\text { Идентифицированные } \\
\text { соединения }\end{array}$} & \multirow{3}{*}{$\mathrm{m} / \mathrm{z}$} & \multicolumn{4}{|c|}{ Объекты исследования } \\
\hline & & \multicolumn{2}{|c|}{$\begin{array}{c}\text { АКН } \\
\text { Фрагменты }\end{array}$} & \multicolumn{2}{|c|}{$\begin{array}{c}\text { АБКН } \\
\text { Фрагменты }\end{array}$} \\
\hline & & $\mathrm{C}-\mathrm{S}-$ связи & С-О-связи & C-S-связи & С-О-связи \\
\hline 1 & 2 & 3 & 4 & 5 & 6 \\
\hline \multicolumn{6}{|c|}{ Насыщенные } \\
\hline Алканы & 57,71 & $\mathrm{C}_{12}-\mathrm{C}_{37}$ & $\mathrm{C}_{14}-\mathrm{C}_{36}$ & $\mathrm{C}_{12}-\mathrm{C}_{31}$ & $\mathrm{C}_{14}-\mathrm{C}_{32}$ \\
\hline Алкены & & $\begin{array}{c}\mathrm{C}_{14: 1}, \mathrm{C}_{16: 1}, \mathrm{C}_{18: 1} \\
\mathrm{C}_{20: 1}\end{array}$ & Не уст-ны & Не уст-ны & Не уст-ны \\
\hline Изоалканы & 71 & $\mathrm{C}_{19} \mathrm{H}_{40}, \mathrm{C}_{20} \mathrm{H}_{42}$ & Не уст-ны & $\mathrm{C}_{14-} \mathrm{C}_{15} \mathrm{C}_{19}-\mathrm{C}_{20}$ & Не уст-ны \\
\hline Циклопентаны & 69 & $\mathrm{C}_{15}-\mathrm{C}_{24}$ & $\mathrm{C}_{17-} \mathrm{C}_{26}$ & Не уст-ны & $\mathrm{C}_{15-} \mathrm{C}_{24}$ \\
\hline Циклогексаны & 82,83 & $\mathrm{C}_{17}-\mathrm{C}_{21}$ & $\mathrm{C}_{17}-\mathrm{C}_{25}$ & $\mathrm{C}_{18}-\mathrm{C}_{22}$ & Не уст-ны \\
\hline $\begin{array}{l}\text { Терпаны (хейлантаны, } \\
\text { гопаны) }\end{array}$ & $\begin{array}{l}191 \\
177\end{array}$ & $\mathrm{C}_{27}, \mathrm{C}_{29}-\mathrm{C}_{35}$ & $\mathrm{C}_{27}, \mathrm{C}_{29}-\mathrm{C}_{33}$ & $\mathrm{C}_{23}-\mathrm{C}_{26}, \mathrm{C}_{27}-\mathrm{C}_{32}$ & $\mathrm{C}_{27}, \mathrm{C}_{29}-\mathrm{C}_{31}$ \\
\hline Стераны & $\begin{array}{l}217 \\
218\end{array}$ & $\mathrm{C}_{27}-\mathrm{C}_{29}$ & $\mathrm{C}_{27}-\mathrm{C}_{29}$ & $\mathrm{C}_{21}, \mathrm{C}_{22}$ & $\mathrm{C}_{27}-\mathrm{C}_{30}$ \\
\hline
\end{tabular}

Ароматические

моноциклические

$\begin{array}{lccccr}\text { Н-алкилбензолы } & 92 & \mathrm{C}_{15}-\mathrm{C}_{26} & \mathrm{C}_{18-} \mathrm{C}_{30} & \mathrm{C}_{15}-\mathrm{C}_{23} & \text { Не уст-ны } \\ \text { Фенилалканы } & 91 & \mathrm{C}_{17}-\mathrm{C}_{18} & \text { Не уст-ны } & \mathrm{C}_{17}-\mathrm{C}_{18} & \text { Не уст-ны } \\ \text { Алкилтолуолы } & 105 & \mathrm{C}_{16}-\mathrm{C}_{29} & \mathrm{C}_{18}-\mathrm{C}_{29} & \mathrm{C}_{16}-\mathrm{C}_{22} & \text { Не уст-ны } \\ \text { Алкилксилолы } & 119 & \mathrm{C}_{17}-\mathrm{C}_{19} & \text { Не уст-ны } & \mathrm{C}_{17}-\mathrm{C}_{19} & \text { Не уст-ны } \\ \text { Триметилалкилбензолы } & 133 & \mathrm{C}_{15}-\mathrm{C}_{21} & \text { Не уст-ны } & \mathrm{C}_{15}, \mathrm{C}_{17}-\mathrm{C}_{20} & \text { Не уст-ны }\end{array}$

бициклические

\begin{tabular}{|c|c|c|c|c|c|}
\hline Нафталины & $\begin{array}{l}141, \\
156, \\
170, \\
184\end{array}$ & $\mathrm{C}_{2}-\mathrm{C}_{5}$ & Не уст-ны & $\mathrm{C}_{2-} \mathrm{C}_{4}$ & Не уст-ны \\
\hline Дифенилы & $\begin{array}{c}154 \\
168, \\
182\end{array}$ & $\mathrm{C}_{0}-\mathrm{C}_{2}$ & Не уст-ны & $\mathrm{C}_{0}$ & $\mathrm{C}_{1}$ \\
\hline
\end{tabular}


Продолженение таблицы 3

Continuation of Table 3

\begin{tabular}{|c|c|c|c|c|c|}
\hline 1 & 2 & 3 & 4 & 5 & 6 \\
\hline \multicolumn{6}{|c|}{ трициклические } \\
\hline Фенантрены & $\begin{array}{c}178,192 \\
206, \\
220,234\end{array}$ & $\mathrm{C}_{0}-\mathrm{C}_{4}$ & Не уст-ны & $\mathrm{C}_{0}$ & $\mathrm{C}_{0}, \mathrm{C}_{2}-\mathrm{C}_{4}$ \\
\hline Флуорен & $\begin{array}{l}166,180 \\
194,208\end{array}$ & $\mathrm{C}_{0}-\mathrm{C}_{3}$ & Не уст-ны & $\mathrm{C}_{0}$ & \\
\hline \multicolumn{6}{|c|}{ тетрациклические } \\
\hline Флуорантен, пирен & 202 & $\mathrm{C}_{0}-\mathrm{C}_{2}$ & Не уст-ны & Не уст-ны & Не уст-ны \\
\hline Хризен & 228 & $\mathrm{C}_{0}-\mathrm{C}_{2}$ & Не уст-ны & Не уст-ны & Не уст-ны \\
\hline \multicolumn{6}{|c|}{ пентациклические } \\
\hline Перилен & 252 & $\mathrm{C}_{0}-\mathrm{C}_{2}$ & Не уст-ны & Не уст-ны & Не уст-ны \\
\hline Бензофлуорантен & 252 & $\mathrm{C}_{0}-\mathrm{C}_{2}$ & Не уст-ны & Не уст-ны & Не уст-ны \\
\hline \multicolumn{6}{|c|}{ Гетероорганические } \\
\hline Дибензотиофены & $\begin{array}{c}184,198 \\
212,226 \\
240\end{array}$ & $\mathrm{C}_{0}-\mathrm{C}_{3}$ & Не уст-ны & Не уст-ны & Не уст-ны \\
\hline $\begin{array}{l}\text { Метиловые эфиры } \\
\text { алкановых кислот }\end{array}$ & 74 & $\mathrm{C}_{15}-\mathrm{C}_{25}$ & Не уст-ны & $\mathrm{C}_{15}-\mathrm{C}_{31}$ & Не уст-ны \\
\hline $\begin{array}{l}\text { Этиловые эфиры } \\
\text { алкановых кислот }\end{array}$ & 88 & Не уст-ны. & Не уст-ны & Не уст-ны & Не уст-ны \\
\hline Бициклические сульфиды & 183 & Не уст-ны. & Не уст-ны & $\mathrm{C}_{14}, \mathrm{C}_{15}-\mathrm{C}_{19}$ & Не уст-ны \\
\hline Алифатические спирты & 55 & Не уст-ны. & $\mathrm{C}_{14-} \mathrm{C}_{16}$ & Не уст-ны & $\mathrm{C}_{14}, \mathrm{C}_{17}-\mathrm{C}_{18}$ \\
\hline
\end{tabular}
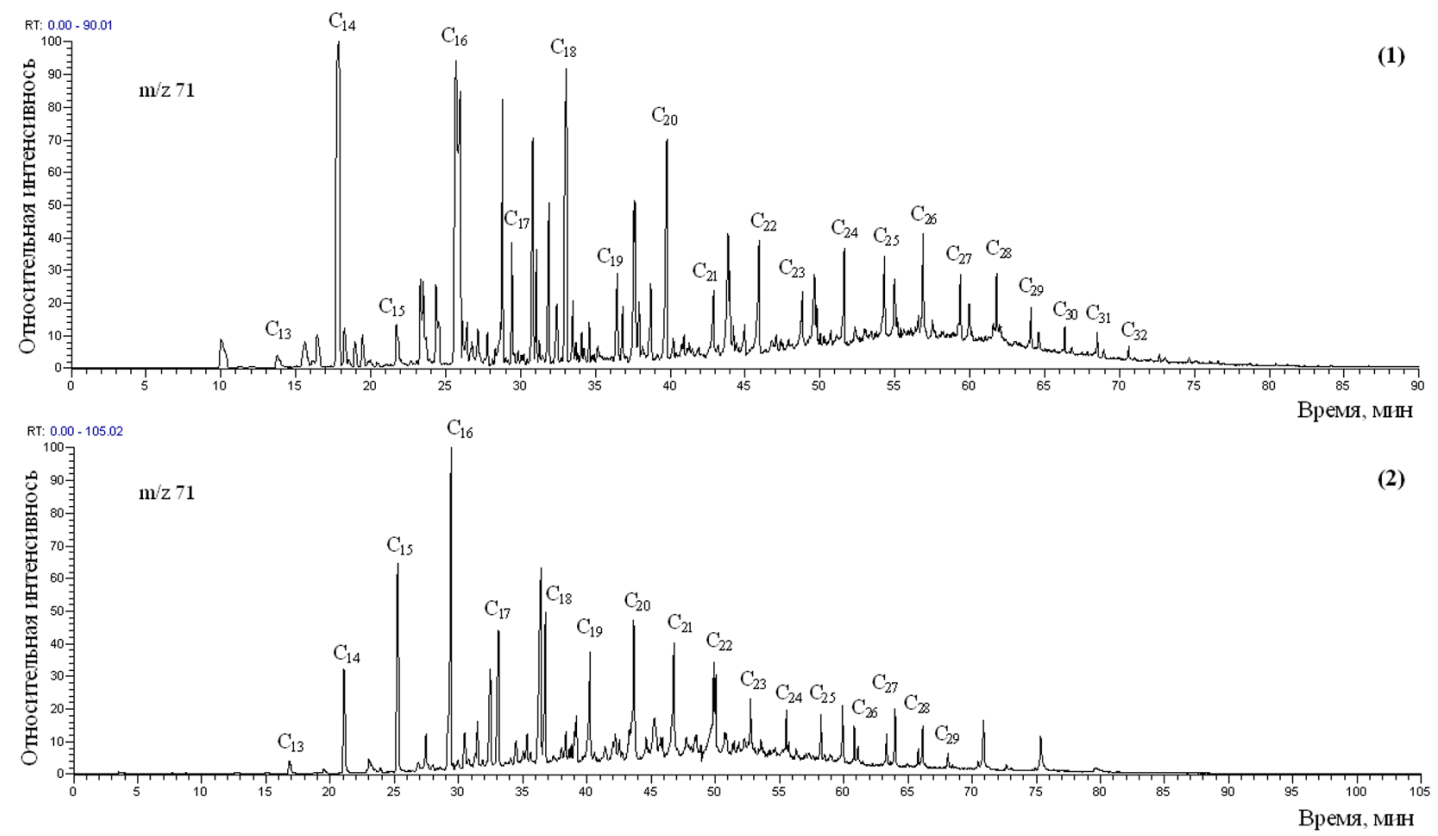

Рис. 2. Масс-фрагментограмма продуктов десульфуризазии АКН (1) и АБКН (2) m/z 71 (н-алканы)

Fig. 2. Mass-fragmentograms of desulphurization products of AKO (1) and ABKO (2) m/z 71 (n-alkanes) 
Отличительной особенностью «серосвязанных» алканов в структуре АБКН является более высокое относительное содержание в их составе гомологов с нечетным числом атомов углерода в цепи и снижение доли разветвленных алканов (метилалканов). По сравнению с АКН в продуктах десульфуризации АБКН отсутствуют алкены. Это может быть связано с тем, что, будучи реакционно-способными соединениями, они образуют кислородные соединения при взаимодействии с продуктами жизнедеятельности микроорганизмов.

«Серосвязанные» моноциклические нафтены в структуре АКН представлены алкилциклопентанами и алкилциклогексанами. В продуктах десульфуризации АБКН установлены только алкилциклогексаны. Известно, что циклогексаны более устойчивы к биодеградации, чем циклопентаны [14]. В смеси полициклических нафтенов, связанных с ядром молекул АКН и АБКН сульфидными мостиками, присутствуют терпаны и стераны. Особенность «серосвязанных» полициклоалканов АБКН - появление в их составе низкомолекулярных структур ( $\mathrm{C}_{23}-\mathrm{C}_{26}$ терпанов и $\mathrm{C}_{21}-\mathrm{C}_{22}$ стеранов). Сведения о порядке деградации гопанов и стеранов довольно противоречивы. В работах $[14,15]$ показано, что в первую очередь деградируют гопановые структуры, а в работе [16] - стерановые. Считается, что селективность биодеградации полициклических нафтенов зависит от типа бактериальной популяции [14].

Моноарены в продуктах десульфуризации АКН и АБКН представлены н-алкилбензолами, фенилалканами, алкилтолуолами, алкилксилолами и триметилалкилбензолами. В составе «серосвязанных» гомологов бензола образца АБКН резко снижается относительное содержание н-алкилбензолов, которые хорошо идентифицируются в исходном образце (рис. 3). На хрома-
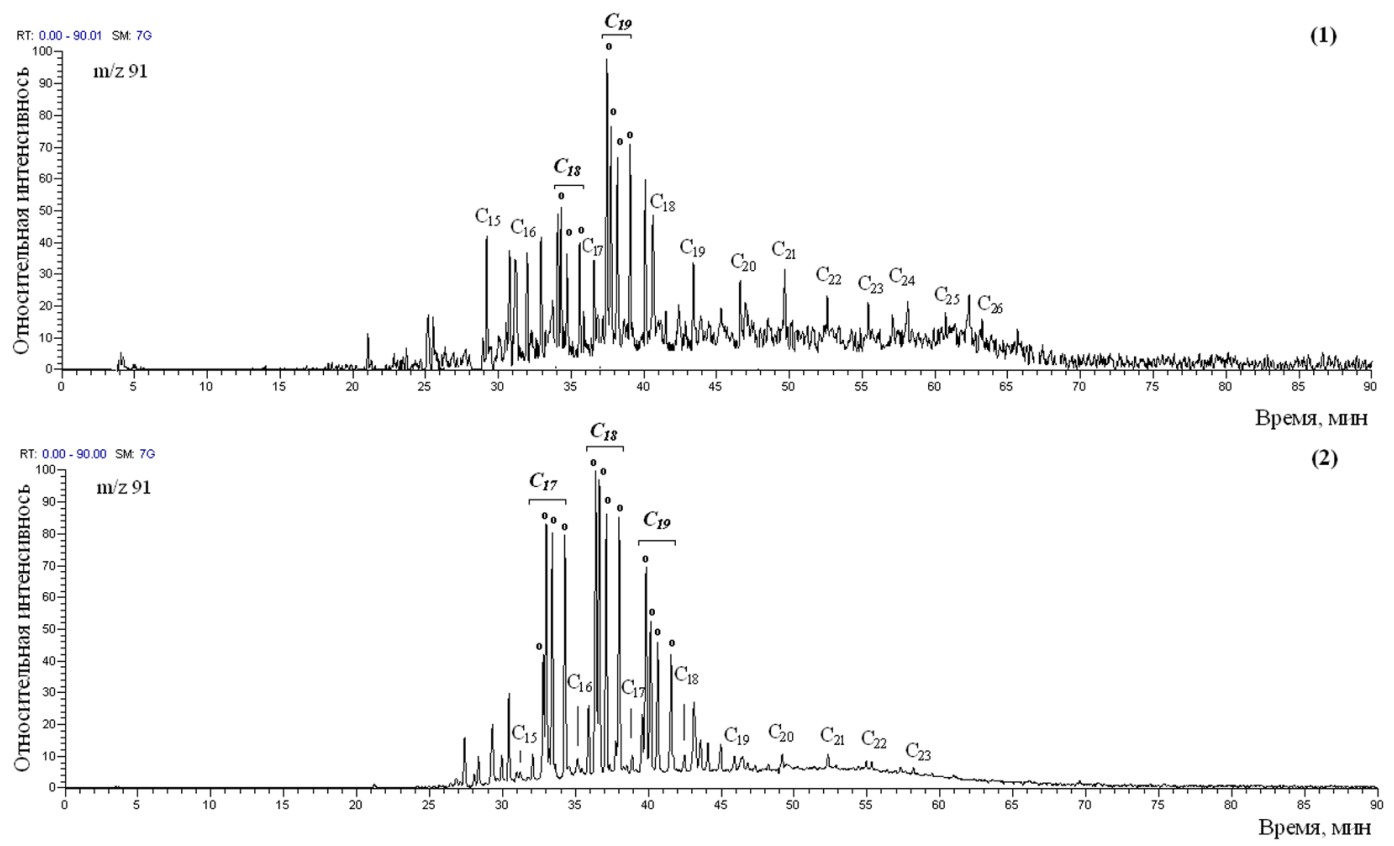

Рис. 3. Масс-фрагментограмма продуктов десульфуризации АКН (1) и АБКН (2) m/z91,92 (н-алкилбензолы, фенилалканы)

Fig. 3. Mass fragmentograms of AKO (1) and ABKO (2) desulphurization products 91,92 (n-alkylbenzenes, phenylalkanes) 
тограмме по m/z 91 АБКН в отличие от АКН фиксируются высокие пики, характеризующие повышенные концентрации фенилалканов $\mathrm{C}_{17}-\mathrm{C}_{19}$ с различным положением фенильного заместителя в алкильной цепи.

В составе биаренов обнаружены нафталины и фенантрены. В АБКН по сравнению с АКН не идентифицируются метилнафталины, существенно снижена концентрация $\mathrm{C}_{2}-\mathrm{C}_{4}$ нафталинов и фиксируются пики, характеризующие наличие $\mathrm{C}_{3}$ и $\mathrm{C}_{4}$ фенантренов.

Среди гетероорганических соединений продуктов десульфуризации АКН и АБКН присутствуют алифатические кислоты в форме метиловых эфиров (рис. 4) [17]. Увеличение их доли в составе гетероорганических соединений АБКН, вероятнее всего, связано с дополнительным образованием таких соединений в процессе бактериального окисления [5]. Отсутствие дибензотиофенов в продуктах деструкции сульфидных связей в молекулах АБКН может быть обусловлено десульфуризацией этих соединений в присутствии борида никеля [18].

Изменения в составе «эфиросвязанных» фрагментов в АБКН менее заметны, чем изменения в составе «серосвязанных» фрагментов АКН. Практически нет различий в количестве и молекулярно-массовом распределении идентифицированных насыщенных углеводородов и гетероорганических соединений. Наиболее заметно образцы АБКН и АКН отличаются по составу «эфиросвязанных» ароматических УВ. Среди соединений, идентифицированных в продуктах разрушения эфирных мостиков в структуре АБКН, они не установлены.
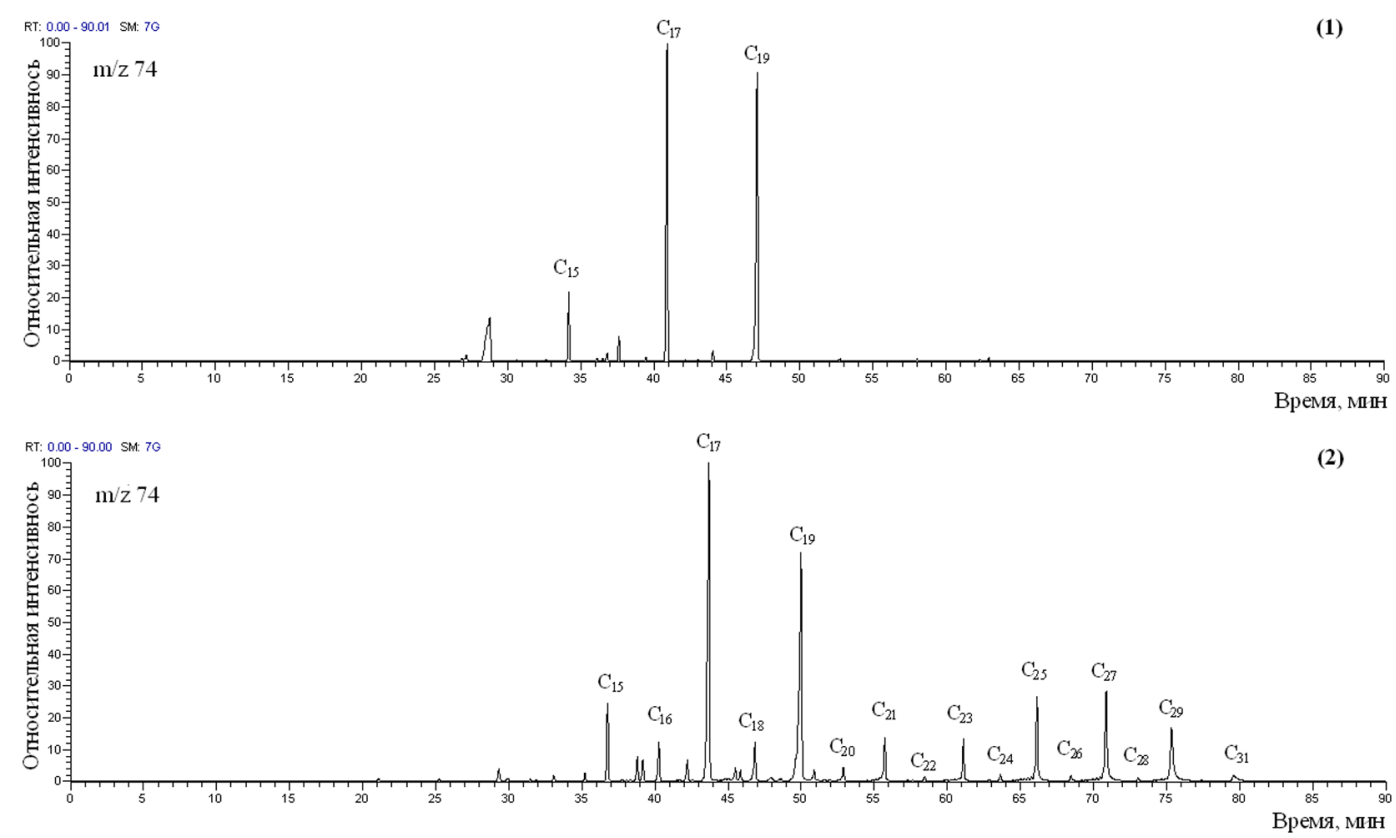

Рис. 4. Масс-фрагментограмма продуктов десульфуризации АКН (1) и АБКН (2) m/z 74 (метиловые эфиры алкановых кислот)

Fig. 4. Mass fragmentograms of AKO (1) and ABKO (2) m/z 74 (methyl esters of alkanic acids) desulphurization products 
Обобщение результатов исследования позволяет сделать следующее заключение.

В процессе биохимического окисления и под влиянием абиотических факторов среды происходит деструкция асфальтенов нефти Крапивинского месторождения, которая сопровождается повышением степени ароматичности их молекул и увеличением в их структуре доли фрагментов, содержащих гидроксильные, карбоксильные, эфирные и сульфоксидные группы. Снижение доли алифатических фрагментов и появление кислородных функций напрямую доказывает окислительный характер протекающих процессов биотрансформации геомакромолекул.

С использованием селективных химических реакций показано, что в структуре асфальтенов биодеградированной нефти, как и в структуре исходного образца, присутствуют «эфиро- и серосвязанные» фрагменты. Основными представителями являются нормальные и разветвленные алканы, моно- и полициклоалканы, моно- и бициклические ароматические углеводороды, гетероорганические соединения.

Отличительные особенности «серосвязанных» фрагментов асфальтенов биодеградированной нефти: отсутствие в их составе алкенов, более высокое относительное содержание н-алканов с нечетным числом атомов углерода, снижение доли разветвленных алканов, отсутствие алкилциклопентанов, появление низкомолекулярных терпанов и стеранов, снижение относительного содержания н-алкилбензолов, нафталинов, увеличение концентрации фенилалканов и фенантренов, увеличение доли кислот и отсутствие дибензотиофенов.

Изменения в составе «эфиросвязанных» фрагментов в АБКН менее заметны. При отсутствии в наборе идентифицированных насыщенных УВ и гетероорганических соединений в продуктах разрушения эфирных мостиков в структуре АБКН не установлены ароматические УВ.

Выявленные различия в составе «связанных» фрагментов, вероятнее всего, отражают специфику строения асфальтенов легкой крапивинской нефти. Можно предположить, что в их структуре присутствуют молекулы, различающиеся по природе и положению алкилсульфидных и эфирных мостиковых связей.

\section{Благодарности / Acknowledgements}

Работа выполнена в рамках государственного задания ИХН СО РАН, финансируемого Министерством науки и высшего образования Российской Федерации (НИОКТР 121031200185-6).

This work was supported by the Ministry of Science and Higher Education of the Russian Federation (Registration Number 121031200185-6).

\section{Список литературы / References}

1. Foss L.E., Fahretdinov P.S., Romanov G.V. Study on the Effect of Polyammonium Compounds on Asphaltene-Resin-Wax Precipitation on Polymer Coatings. Oil \& Gas Technologies 2014. Vol. 93 (4), P. 29-32.

2. Yang X., Kilpatrick P. Asphaltenes and waxes do not interact synergistically and coprecipitate in solid organic deposit. Energy \& Fuels. 2005. Vol. 19(4), P. 1360 - 1375.

3. Pavel Kriz, Simon I. Andersen. Effect of asphaltenes on crude oil wax crystallization. Energy \& Fuels. 2005. Vol. 19(3), P. 948-953.

4. Иванова И.А., Ибрагимов Р.К., Ибрагимова Д.А. Обзор микробиологических способов борьбы с отложениями высокомолекулярных компонентов нефти. Вестник технологического

$$
-261-
$$


университета 2015. T. 18(20), C. 137-143. [Ivanova I.A., Ibragimov R.K., Ibragimova D.A. Review of microbiological methods of struggle against deposits of high-molecular oil components. Bulletin of the Technological University 2015. Vol. 18(20), P. 137-143. (In Russ.)]

5. Jenisch-Anton A., Adam P., Michaelis W., Connan J., Herrmann D., Rohmer M. and Albrecht P. Molecular evidence for biodegradation of geomacromolecules. Geochimica et Cosmochimica Acta, 2000. Vol. 64(20), P. 3525-3537.

6. Kopytov M.A., Filatov D.A., Altunina L.K. Biodegradation of high-molecular-mass heteroatomic components of heavy oil. Petroleum Chemistry 2014. Vol. 54. (1), P. 58-64.

7. Филатов Д.А., Кривцов Е.Б., Свириденко Н.Н., Головко А.К., Алтунина Л.К. Биогенное окисление высоковязкой нефти Ашальчинского месторождения и ее гетероорганических соединений. Нефтехимия 2017. Т. 57(4), С. 386-393. [Filatov D.A., Krivtsov E.B., Sviridenko N.N., Golovko A.K., Altunina L.K. Biogenic oxidation of high-viscosity oil of the Ashalchinskoye field and its hetero-organic compounds. Petrochemistry 2017. V. 57(4), P. 386-393. (In Russ.)]

8. Cheshkova T.V., Sergun V.P., Kovalenko E.Yu., Gerasimova N.N., Sagachenko T.A., Min R.S. Resins and Asphaltenes of Light and Heavy Oils: Their Composition and Structure. Energy \& Fuels 2019. Vol. 33(9), P. 7971-7982.

9.https://neftegaz.ru/tech-library/mestorozhdeniya/142262-krapivinskoe-neftyanoemestorozhdenie-yugo-zapadnaya-chast/

10. ГОСТ 11858-66. Нефть и нефтепродукты. Метод определения содержания асфальтовосмолистых веществ. Методы испытаний. [GOST 11858-66. Oil and petroleum products. Method for determining the content of asphalt-resinous substances. Methods of testing. (In Russ.)]

11. Peng P., Morales-Izquierdo A., Lown E.M., Strausz O.P. Additional structural details on Athabasca asphaltene and their ramifications. Energy Fuels 1999. Vol. 13(2), P. 248-265.

12. Strel'nikova E.B., Serebrenikova O.V., Ryabova N.V. Classification of Jurassic oils from Southeastern west Siberia IR data. Petroleum Chemistry 2008. Vol. 48(6), P. 420-427.

13. Green J.B., Yu S. K.-T., Pearson C.D., Reynolds J.W. Analysis of sulfur compound types in asphalt. Energy Fuels 1993. Vol. 7, P. 119-126.

14. Peters K.E, Walters C.C, Moldowan J.M. The biomarker guide. New York, Cambridge. University Press, 2007, v. 1, 471 p.; v. 2, 684 p.

15. Moldowan J.M., Seifert W.K. Structure proof and significance of stereoisomeric 28,30-bisnorhopanes in petroleum and petroleum source rocks. Geochemica et Cosmochimica Acta 1984. Vol. 48(8), P. 1651-1661.

16. Killops S.D., Nytoft H.P., di Primio R. Biodegradative production and destruction of norhopanes - An example from residual oil in a Paleogene paleomigration conduit on the Utsira High, Norwegian North Sea. Organic Geochemistry 2019. Vol. 138, P. 1-13.

17. Cheshkova T.V., Kovalenko E.Y., Gerasimova N.N., Sagachenko T.A., Min R.S. Composition and structure of resinous components of heavy oil from the USA oilfield. Petroleum Chemistry 2017. Vol. 57(1), P. 31-38.

18. Sergun V.P., Cheshkova T.V., Sagachenko T.A., Min R.S. Structure units with sulfur and ether/ ester bonds in molecules of high- and low-molecular-weight asphaltenes of USA heavy oil. Petroleum Chemistry 2016. Vol. 56(1), P. 10-15. 